\title{
A review of Canadian forest vegetation management research and practice
}

\author{
Dean G. ThOMPSON*, Douglas G. PITT \\ Natural Resources Canada, Canadian Forest Service, 1219 Queen St. East, Sault Ste. Marie, Ontario, P6A 2E5, Canada
}

(Received 24 June 2002; accepted 19 February 2003)

\begin{abstract}
Research and practice in Canadian forest vegetation management was reviewed for the period 1990 to present. Results indicate continued evolution toward a more integrated and ecologically sound program with appropriate focus on key competitors and crop species. Increasing collaboration between academia, government and industry has resulted in $>666$ new scientific publications, substantially augmenting the existing knowledge base. The development of (Chondrostereum purpureum) as the first biocontrol agent in Canadian forest vegetation management and the use of nutrient-loaded seedlings to enhance establishment success are considered key research highlights. Recent trends in operational practice include a move toward more intensive management on higher quality sites and adoption of innovative approaches (e.g. nutrient loaded seedlings, larger planting stock) and advanced technologies (e.g. electronic guidance in aerial herbicide applications). The lack of long-term growth response data and economic analyses demonstrating positive cost/benefits remain as shortcomings, however continued development of the program will undoubtedly enhance sustainable wood supply and minimize impact on the forest environment.
\end{abstract}

vegetation / management / Canada / review

Résumé - Recherche sur la gestion de la végétation forestière au Canada et les pratiques : une revue. Le présent document passe en revue la recherche sur la gestion de la végétation forestière au Canada et les pratiques à cet égard depuis les années 1990 jusqu'à ce jour. Les résultats de cet examen révèlent une progression continue vers un programme plus intégré et plus respectueux de l'environnement, axé, fort judicieusement sur les principales espèces concurrentes et les espèces du peuplement final. La collaboration accrue du monde universitaire, des gouvernements et de l'industrie s'est traduite par la parution de plus de 666 nouvelles publications scientifiques qui ont considérablement enrichi la base des connaissances actuelles. La mise au point au Canada du Chondrostereum purpureum comme premier bioherbicide et l'utilisation de semis gorgés d'éléments nutritifs afin d'accroître le taux de réussite de l'établissement sont considérées comme des grandes percées de la recherche. Parmi les tendances récentes en matière de pratiques opérationnelles figurent le recours à des méthodes de gestion plus intensive dans les stations à indice de qualité plus élevé et l'adoption de méthodes novatrices (p. ex., semis gorgés d'éléments nutritifs) et de techniques de pointe (p. ex., système de guidage électronique des applications aériennes d'herbicide). Même si les données sur le taux de croissance à long terme des semis et les analyses économiques mettant en évidence les effets positifs sur le plan coûts-avantages font encore défaut, l'évolution incessante du programme améliorera sans aucun doute l'approvisionnement durable en bois et réduira au minimum les répercussions sur le milieu forestier.

gestion / végétation / Canada

\section{INTRODUCTION}

Representing approximately $10 \%$ of the global forested landmass, Canada's forests are key elements in biogeochemical cycling and biodiversity [31]. Specifically, our forests are important carbon sinks and provide habitat for an estimated 140000 species of plants, animals and microorganisms, including 85 species that are considered as forest dependent and at risk of extinction [53]. Forests cover almost one-half of our country and are one of the unique features defining our nation. Based on marked differences in topography, soils, climate and dominant tree species, several distinct forest regions are recognized in Canada (Fig. 1). Many of Canada's forest regions are dominated by softwood species (68\%), with mixed-woods (18\%) and hardwoods (15\%), being most prevalent and economically important in the southern Great Lakes - St. Lawrence, Carolinean and Acadian forest regions.

Unlike many other nations, $94 \%$ of Canadian forests are owned by the public [31] and managed on their behalf by provincial and territorial governments. Forest industry is allowed to extract timber resources under a system with similarities to landlord-tenant lease arrangements [93]. In this context, management of the Canadian forest resource may be viewed as an attempt to strike a sustainable balance among a diverse array of economic, environmental, aesthetic, and spiritual values. Erdle [26] recently described the potential conflicts, tradeoffs

\footnotetext{
*Corresponding author: dthompso@nrcan.gc.ca
} 


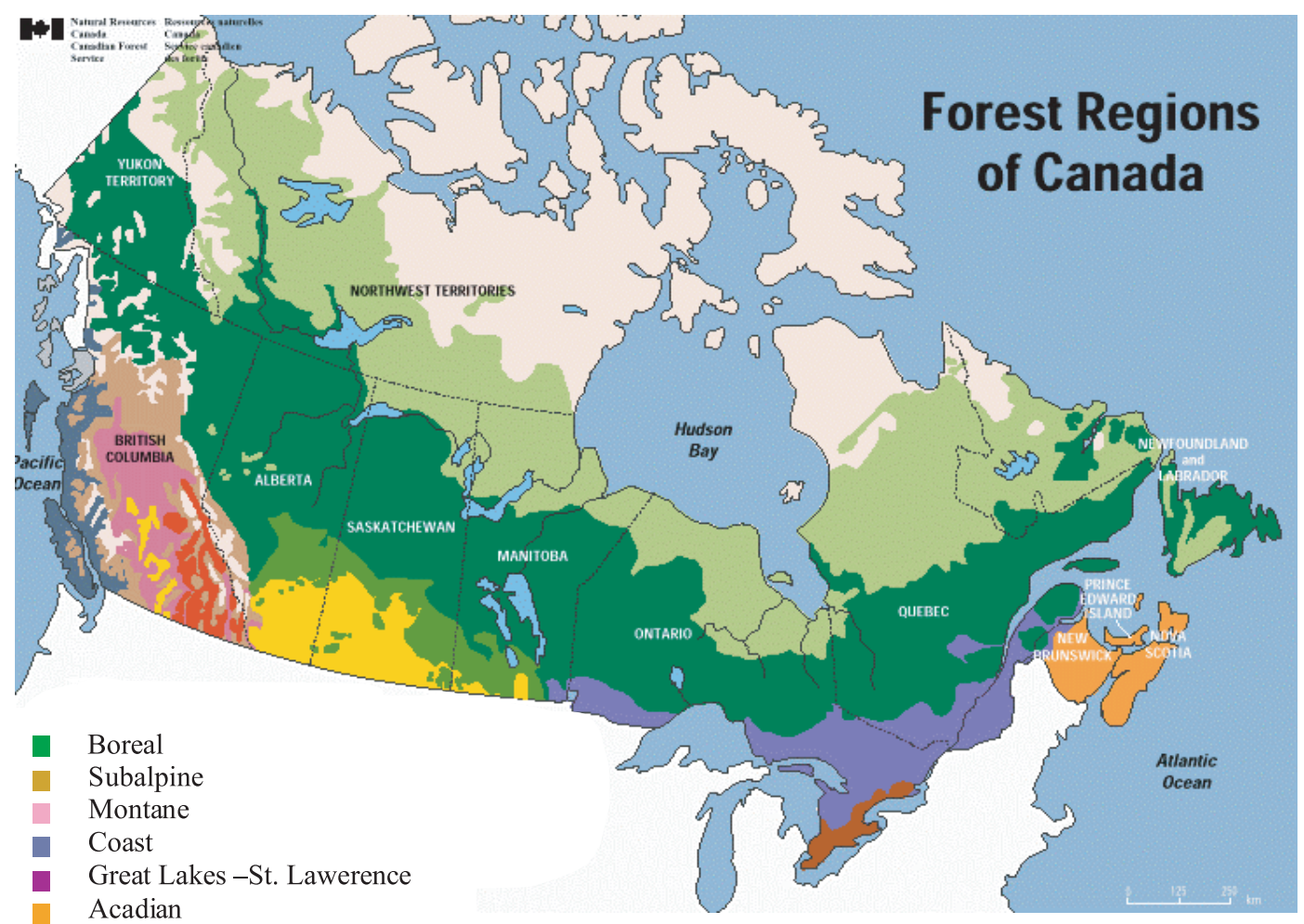

\section{Principal Crop Tree Species}

Boreal - White and black spruce, Balsam fir, Jack pine, White Birch, Poplar

Subalpine - Englemann spruce, Lodgepole pine

Montane - Lodgepole pine, Pitch pine, Poplar

Coast - Red cedar, Hemlock, Sitka spruce, Douglas fir

Great Lakes -St. Lawerence - Red and White pine, Beech, Maple, Red oak,

Acadian -Red and Black spruce, Balsam fir, Yellow Birch

Figure 1. Major forest regions and associated principal crop tree species in Canada (a colour version of this figure is available online at http://www.edpsciences.org/afs).

and mitigating strategies associated with managing forested lands for a variety of values. The latter paper clearly reflects the complex and dynamic mixture of policy, politics, emotion and science, which are pervasive in Canadian forest management.

Although management of the Canadian forest resource is inherently complex, a number of fundamental principals apply, including the need for integrated management and sustainable development, management for multiple values across the larger landscape, protection of ecological function and integrity, and protection of sensitive, unique or high value sites. From any perspective - global, national, cultural, environmental or economic - Canadian forests are a critically important renewable resource worthy of our best management efforts.

From an economic viewpoint, commercial timber, pulp, and paper production is central to our national economy. Canada controls a 15 to $30 \%$ share of worldwide lumber, pulp and paper commodities and ranks first in net value of exported forest products [68]. In 1999, the total value of Canadian forest products exports reached an all time high of 44.2 billion dollars. The forestry sector also supports approximately 877000 direct and indirect jobs. These economic benefits are derived from a relatively small proportion $(\sim 50 \%)$ of the total 253.6 million ha considered as commercially productive in Canada (Fig. 2). On an annual basis, the utilization rate or Annual Allowable Cut (AAC), approximates 1 million ha, equating to $\sim 0.2 \%$ of the total forested land area.

Canada is blessed with a generally vast and diverse forest resource. However, only a small portion of the land base is commercially viable and directly managed for derivation of economic benefits. This portion is being continuously diminished by demands for urban, agriculture, parks, recreation and other alternate land uses. On such a diminishing commercial forest landbase, the practice of vegetation management is one 




Total Forest Land $=417.6 \mathrm{M}$ ha

Figure 2. Relative proportion of annual harvest, productive and nonproductive forest comprising the total forested land base in Canada.

of the principal means of optimizing productive capacity [91]. Sufficient knowledge of forest ecology, inter- and intra-species competition mechanisms and thresholds, and plant succession allows management of competing vegetation to meet specific silvicultural or wildlife management goals. The intensity of forest management applied to a particular site is based on site-specific prescriptions formulated by professional forest managers and may be classified on a gradient of intensity typically referred to as extensive (natural regeneration only) through basic (including assisted natural and artificial regeneration) to intensive (multiple interventions). The highest level of intensity approaches that used in agricultural production scenarios [3, $19,25,52,90]$. In this regard, and in comparison to many other forest producing nations, the current vegetation management program in Canada is generally characterized by single, lowintensity interventions on a small proportion of potential sites, and may be considered as basic management.

Several previous reviews have dealt with vegetation management in Canada to varying degrees [15-17, 18, 27, 78, 81, 93], however many of these were focused on the use and optimization of chemical herbicides. Most recently, Wagner and Colombo [85] published an excellent text documenting the principles and practices of vegetation management and forest regeneration with a particular focus on the province of Ontario. The objective of this paper, is to synthesize information on forest vegetation management at the national level, by reviewing trends and developments in research and practice over the last decade (1990-present).

\section{MATERIALS AND METHODS}

The Canadian Forest Pest Management (CFPM) database (http:// www.glfc.cfs.nrcan.gc.ca/cfpm) and the National Forestry Database Program (NFDP) (http://nfdp.ccfm.org) were used to assess trends in Canadian forest vegetation management research and practice, respectively, from 1990 to present. Both databases are freely and universally accessible via the Internet and both are hosted and maintained by the Canadian Forest Service, Natural Resources Canada.
Basic information from these two sources was augmented by information gathered through an informal electronic questionnaire sent to a number of leading researchers, industrial foresters, and academics from across the country. The questionnaire attempted to get a broader perspective on the adequacy of Canadian forest vegetation management research, knowledge and techniques.

At the time when searches were conducted, the CFPM database [75] comprised approximately 11000 scientific publication records, each including abstracts and an extensive list of data fields facilitating search, selection and sorting functions. For the purposes of this paper, several queries of the database were invoked using the advanced search function to look for specific terms (e.g. "release", "efficacy" or "site preparation") in one or more of the various data fields (e.g. keyword, management technique, abstract, title). All searches were restricted to records originating in Canada, having vegetation management as their primary focus and with publication dates of 1990 or later. Where information pertinent to a particular species or province was sought, appropriate keywords were specified in the name of competing vegetation, crop species fields or province/state fields, respectively.

The NFDP was founded by the Canadian Council of Forest Ministers (CCFM) in 1990 and provides a comprehensive source of statistical data and information describing the nature, extent and change in Canada's forest resources through time. The NFDP also provides information on how these resources are being managed, their economic contribution to Canadian society, and expenditures required to maintain healthy forests. For the purposes of this review, information contained within the "Compendium of Canadian Forestry Statistics" in subsections on forest inventory, silviculture and pest control product use were particularly valuable.

\section{RESULTS}

\subsection{Recent trends in Canadian forest vegetation management practice}

Harvesting is clearly the major anthropogenic disturbance influencing the development of most managed forest stands. As such, it is the key factor controlling the type and amount of competing vegetation which subsequently occupies the site. Clear-cutting continues to be the major harvesting method used in Canadian silviculture [19], however use of partial harvesting systems has recently increased in virtually every forest region of the country.

Post-harvest regeneration of Canadian forests has largely been achieved through natural means, with planting or seeding playing a much smaller role (Fig. 3). The cumulative regenerating land base accruing since 1975 on crown lands has been estimated at approximately 16 million hectares in 1998 . Trend data [19] suggest that 75 to $80 \%$ of the harvested area has been successfully regenerated seven years after cutting and the proportion of the landbase considered as free from non-crop competition has been increasing slowly but consistently (Fig. 4).

In Canada, forest vegetation management activities are largely conducted within a 5-year period post-harvest on areas successfully regenerated by either natural or artificial means, but which require further treatment to achieve silvicultural objectives. Vegetation that rapidly establishes on newly disturbed forest sites often determines whether forest regeneration will be successful [83]. Many of the principal competitor species in Canadian forestry are perennials that reproduce by both seed and asexual means [14] and are highly adapted for rapid establishment and growth in areas with disturbed soils 




Figure 3. The proportion of Canadian forest lands regenerated using natural and artificial methods (1990-1997).

and high light intensity (Tab. I). Often these species grow in complex mixtures of graminaceous, herbaceous and deciduous brush (e.g., Rubus spp., Calamagrostis sp., Epilobium spp.) posing a threat to crop trees and particularly challenging scenarios for foresters who are required to ensure their successful regeneration. A variety of techniques (manual, mechanical, biological, chemical, prescribed burning, etc.) are available to meet these challenges and may be invoked under one of the following strategies:
(1) Site preparation - treatment that modifies a site prior to planting, seeding, or natural regeneration and which provides conditions favourable to regeneration establishment [19]. Objectives may include slash alignment or compaction to facilitate planting, and/or the creation of suitable microsites for seed germination and seedling growth.

(2) Release - treatment that is applied following regeneration establishment (seeding, planting, or natural regeneration), to free crop trees from vegetative competition. Objectives include the reduction of inter-specific competition and the promotion of diameter growth. [19].

(3) Pre-commercial thinning - treatment applied to juvenile stands of either natural or artificial origin to control stand density and composition [19]. Objectives usually include reducing both inter- and intra-specific competition and the promotion of diameter increment and stand quality. In Canada, release and pre-commercial thinning treatments are often grouped and discussed together as "stand tending".

Historical trend data [19] suggest that the total area being site prepared has been decreasing, while the area released has been relatively constant. The most dramatic change has been in the area pre-commercially thinned, which has approximately doubled from 93 thousand ha in 1990 to 184 thousand ha in 2000. Data for the year 2000 show that the total area receiving some type of vegetation management equated to approximately $76 \%$ of the total 1027222 ha harvested. Similar proportions of the productive forest landbase were treated

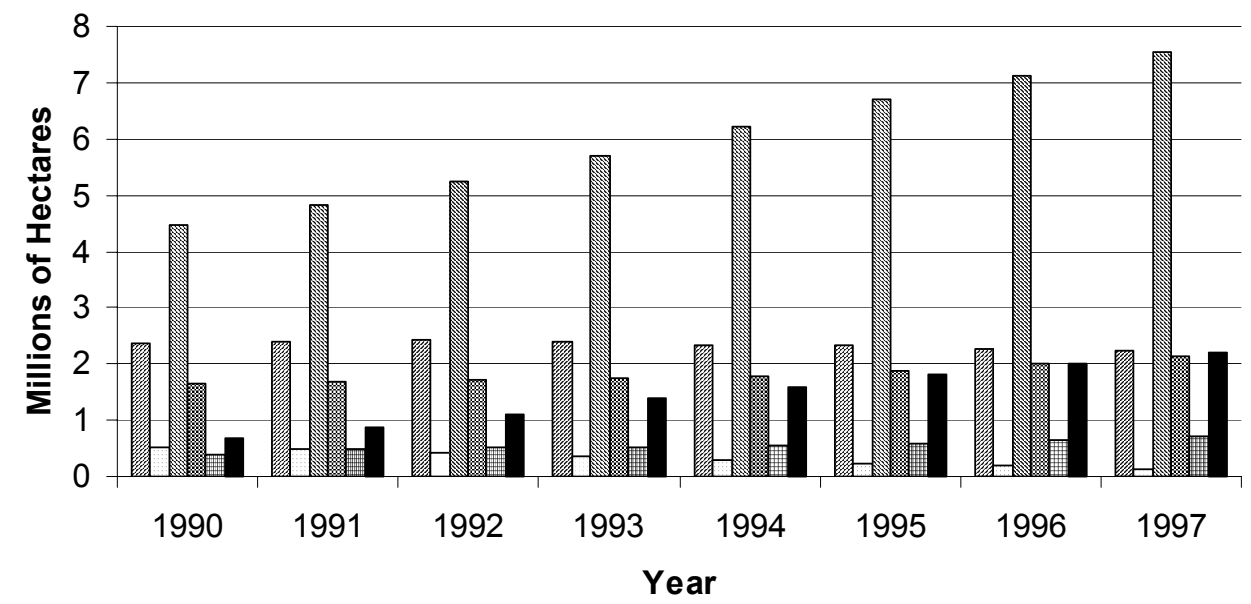

$\square$ Understocked-1 $\square$ Understocked-2 $\square$ Stocked
$\square$ Stocked-FNC $\square$ Enhanced $\square$ Enhanced-FNC

Relatively small portions (total $<0.5$ million ha) of the harvested area were classified as disturbed but without a timber production objective (non-production) or of unknown status in each year but are not shown here. Stocked areas are those where stocking standards have been met, whereas Understocked refers to productive area which does not meet stocking standards, either because they require silvicultural treatment to reach stocking objectives (Understocked-1), or stocking objectives are expected to be achieved through natural recruitment (Understocked-2). Enhanced refers to stocked area where density control standards have been met. Free from non-crop competition (FNC) refers to stocked or enhanced areas where competition control objectives have been met.

Figure 4. The proportion of harvested forest lands meeting various stocking and competition-free classification standards (1990-1997). 
Table I. Key competitor species and control options in Canadian forest vegetation management.

\begin{tabular}{|c|c|c|c|c|c|c|}
\hline $\begin{array}{l}\text { Competitor } \\
\text { genus }\end{array}$ & $\begin{array}{l}\text { Example common } \\
\text { names }\end{array}$ & $\begin{array}{l}\text { Life cycle/ } 1 \\
\text { form }\end{array}$ & $\begin{array}{l}\text { Max height } \\
(\mathrm{m})\end{array}$ & $\begin{array}{l}\text { Modes of } \\
\text { reproduction* }\end{array}$ & $\begin{array}{c}\text { Control options } \\
\text { (in approximate order } \\
\text { of effectiveness) }\end{array}$ & Practices not recommended \\
\hline Calamagrostis & Canada blue-joint grass & $\begin{array}{l}\text { Perennial } \\
\text { grass }\end{array}$ & $1-2$ & $\mathrm{Rh}, \mathrm{Se}$ & $\begin{array}{l}\text { Hexazinone, glyphosate, winter } \\
\text { harvest, partial harvest. }\end{array}$ & $\begin{array}{l}\text { Mechanical site prep., burning, } \\
\text { summer harvest. }\end{array}$ \\
\hline Epilobium & Fireweed & $\begin{array}{l}\text { Perennial } \\
\text { herb }\end{array}$ & $<2$ & $\mathrm{Se}, \mathrm{Rs}, \mathrm{Rh}$ & $\begin{array}{l}\text { Glyphosate, hexazinone, 2,4-D, } \\
\text { winter harvest, partial harvest. }\end{array}$ & $\begin{array}{l}\text { Summer harvest, burning, } \\
\text { mechanical site prep. }\end{array}$ \\
\hline Rubus & $\begin{array}{l}\text { Red raspberry, } \\
\text { salmonberry }\end{array}$ & $\begin{array}{l}\text { Biennial } \\
\text { shrub }\end{array}$ & $2-3$ & Se, Rs, Ss & $\begin{array}{l}\text { Hexazinone, glyphosate, } \\
\text { triclopyr, partial harvest. }\end{array}$ & Cutting, burning, summer harvest. \\
\hline Alnus & $\begin{array}{c}\text { Red, speckled and green } \\
\text { Alder }\end{array}$ & $\begin{array}{l}\text { Perennial } \\
\text { shrub }\end{array}$ & $3-4$ & $\mathrm{Se}, \mathrm{Ss}, \mathrm{St}$ & $\begin{array}{l}\text { Glyphosate, triclopyr, } 2,4-\mathrm{D}, \\
\text { Chondrostereum purpureum, } \\
\text { summer cutting. }\end{array}$ & Dormant cutting. \\
\hline Populus & $\begin{array}{l}\text { Trempling aspen, } \\
\text { balsam poplar }\end{array}$ & Perennial tree & $<34$ & Se, Rs, Ss & $\begin{array}{l}\text { Glyphosate, triclopyr, } \\
\text { summer cutting. }\end{array}$ & $\begin{array}{l}\text { Mechanical site prep., dormant } \\
\text { cutting, spring burning. }\end{array}$ \\
\hline Salix & Willow & $\begin{array}{l}\text { Perennial } \\
\text { shrub }\end{array}$ & $1-6$ & $\mathrm{Se}, \mathrm{Rs}, \mathrm{Ss}, \mathrm{St}$ & $\begin{array}{l}\text { Glyphosate, triclopyr, } \\
\text { summer cutting. }\end{array}$ & $\begin{array}{l}\text { Burning, dormant cutting, } \\
\text { mechanical site prep. }\end{array}$ \\
\hline Acer & $\begin{array}{l}\text { Mountain, striped, red, } \\
\text { bigleaf, and sugar maple }\end{array}$ & $e^{\text {Perennial tree }}$ & $<35$ & $\mathrm{Se}, \mathrm{Ss}$ & $\begin{array}{l}\text { Triclopyr, glyphosate, } \\
\text { summer cutting. }\end{array}$ & Dormant cutting. \\
\hline Betula & White birch & Perennial tree & $<28$ & $\mathrm{Se}, \mathrm{Ss}$ & $\begin{array}{l}\text { Glyphosate, triclopyr, } 2,4-\mathrm{D}, \\
\text { Chondrostereum purpureum, } \\
\text { summer cutting. }\end{array}$ & $\begin{array}{l}\text { Dormant cutting, mechanical } \\
\text { site prep. }\end{array}$ \\
\hline Prunus & Pin cherry & $\begin{array}{l}\text { Perennial } \\
\text { shrub }\end{array}$ & $<5$ & $\mathrm{Se}, \mathrm{Ss}, \mathrm{Rs}$ & $\begin{array}{l}\text { Glyphosate, triclopyr, } 2,4-\mathrm{D}, \\
\text { Chondrostereum purpureum, } \\
\text { summer cutting. }\end{array}$ & $\begin{array}{l}\text { Mechanical site prep., burning, } \\
\text { summer cutting. }\end{array}$ \\
\hline Gaultheria & Salal & $\begin{array}{l}\text { Perennial } \\
\text { shrub }\end{array}$ & $<2$ & Se, Rs & $\begin{array}{c}\text { Glyphosate with siloxane } \\
\text { surfactant, tryclopyr, burning. }\end{array}$ & Mechanical site prep., cutting. \\
\hline Pteridium & Bracken fern & Perennial fern & $<1.5$ & $\mathrm{Se}, \mathrm{Rh}$ & $\begin{array}{c}\text { Glyphosate, hexazinone, } \\
\text { partial harvest. }\end{array}$ & $\begin{array}{l}\text { Mechanical site prep., burning, } \\
\text { cutting. }\end{array}$ \\
\hline Cytisus** & Scotch Broom & $\begin{array}{l}\text { Perennial } \\
\text { shrub }\end{array}$ & $2-3$ & $\mathrm{Se}$ & $\begin{array}{l}\text { Triclopyr, glyphosate with } \\
\text { siloxane surfactant, burning. }\end{array}$ & $\begin{array}{l}\text { Mechanical site prep., dormant cut- } \\
\text { ting, glyphosate without siloxane. }\end{array}$ \\
\hline Ulex** & Gorse & $\begin{array}{l}\text { Perennial } \\
\text { shrub }\end{array}$ & $1.5-3$ & $\mathrm{Se}$ & $\begin{array}{l}\text { Triclopyr, glyphosate with } \\
\text { siloxane surfactant, burning. }\end{array}$ & $\begin{array}{c}\text { Mechanical site prep., glyphosate } \\
\text { without siloxane. }\end{array}$ \\
\hline
\end{tabular}

* Primary methods of reproduction and spreading post establishment, where: $\mathrm{Se}=\mathrm{Seed}, \mathrm{Rs}=\mathrm{Root}$ sucker, $\mathrm{Rh}=\mathrm{Rhizome}, \mathrm{St}=\mathrm{Stolons}, \mathrm{Ss}=\mathrm{Stem}$ or root collar sprouts.

** Recently introduced exotic species.

Sources of information: [14, 21].

by site preparation (306 419 ha) and release (239521 ha), with a somewhat smaller area (183863) receiving pre-commercial thinning treatments. Comparatively small areas received other tending treatments (31 $480 \mathrm{ha}$ ) or scarification (16923 ha).

Among the major forest producing provinces in Canada, clear differences exist in relative use of these three strategies. Such differences are exemplified by comparative data from 1999 (Fig. 5). In that year, the tending program in the province of Quebec was dominated by pre-commercial thinning, whereas release treatments were employed on relatively greater proportions of the landbase in provinces of British Columbia and Ontario. In New Brunswick, the area released was approximately equivalent to that being pre-commercially thinned, while in Alberta and Saskatchewan, only release strategies were employed.

Throughout the 1990s, site preparation was conducted principally by mechanical methods in all provinces, with relatively small areas treated using prescribed burning, chemical, or other techniques. The dominance of mechanical site preparation techniques is exemplified by national level data for 1999 (Fig. 6). Numerous mechanical site preparation treatments, including screefing, mounding, trenching, mixing, subsoiling, clearing, raking, chopping, and masticating are used in Canada, depending upon site conditions, vegetative species on the site, operational constraints, and economics. Treatments are applied using a wide variety of equipment, including chains, with or without shark-finned barrels, Bräcke scarifiers and mounders, disc trenchers, shear blades, ripper teeth, and drum choppers. Ryans and Sutherland [63] provide a detailed synthesis of treatments, equipment and environmental considerations associated with mechanical site preparation pertinent to Ontario and across Canada generally.

In contrast, the aerial application of chemical herbicides was by far the most frequent technique employed in release 


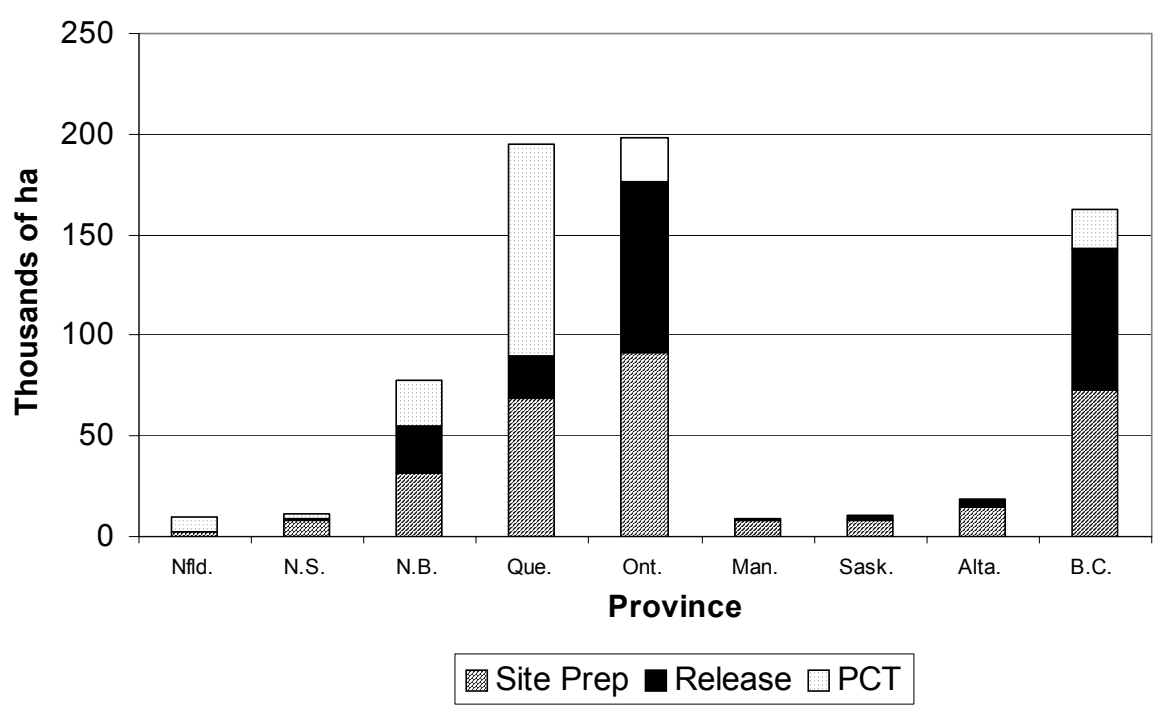

Figure 5. Proportion of forest lands receiving mechanical site preparation, release or pre-commercial thinning treatments by province (1999).

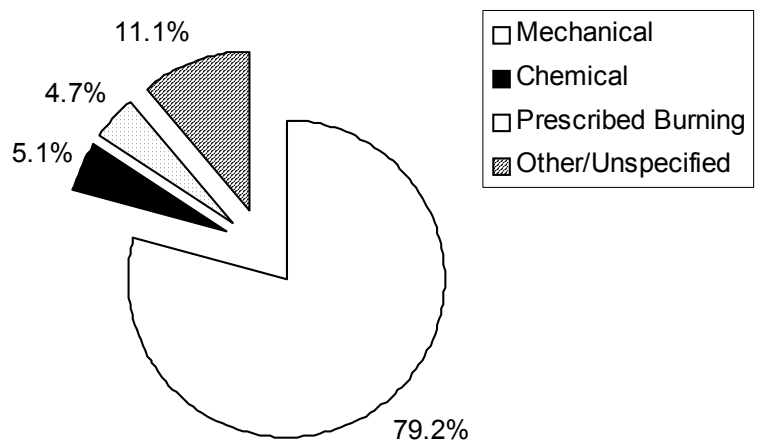

Figure 6. Relative percentage use of various site preparation techniques in Canada.

strategies. Although 5 herbicidal compounds (2,4-D, hexazinone, glyphosate, simazine, and triclopyr) are registered for broadcast use in Canada [19], glyphosate (Vision ${ }^{\circledR}$ ) has accounted for over $90 \%$ of the total forest herbicide-use market throughout the 1990s [19]. While regionally variable, glyphosate was predominantly aerially applied for release of high-value conifers (e.g., jack pine (Pinus banksiana Lamb), black spruce (Picea mariana Mill.), and white spruce (Picea glauca Moench.) from competing vegetation. Through the last decade, herbicide use rates were relatively constant at about 200000 ha per year, equivalent to approximately $20 \%$ of the area harvested annually, or roughly $40 \%$ of the landmass artificially regenerated. The majority $(43 \%)$ of forest area treated with herbicides occurs in the province of Ontario, while New Brunswick and British Columbia use somewhat lesser amounts (Fig. 7). In the province of Quebec, use of chemical herbicides has dropped precipitously since 1995 in anticipation of a ban on the use of forest herbicides which took effect in that province in the summer of 2001.

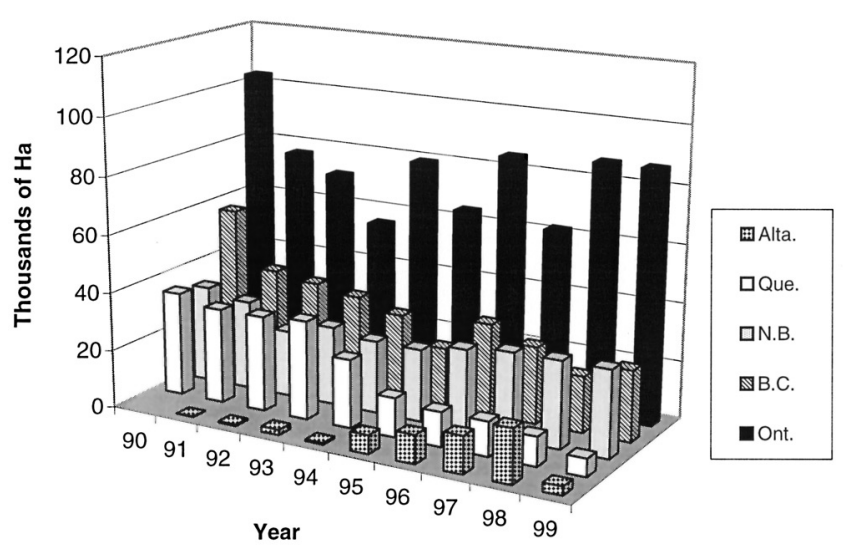

Figure 7. Regenerating forest area treated with chemical herbicides in Canada by year and province.

A number of alternative techniques for controlling competing vegetation (e.g. livestock grazing, mulches, cover crops and biological control agents) are available or under development, but with the exception of livestock grazing in western Canada [22], none have been widely used in operational practice to date.

\subsection{Recent trends in Canadian forest vegetation management research}

A search of the CFPM database reveals that 1256 (11\%) of the current 11260 scientific publication records currently within the CFPM database relate directly to forest vegetation management in Canada. Of these, 666 were published since 1990 and the principal focus of Canadian publications since 


\section{A. Management Strategies}

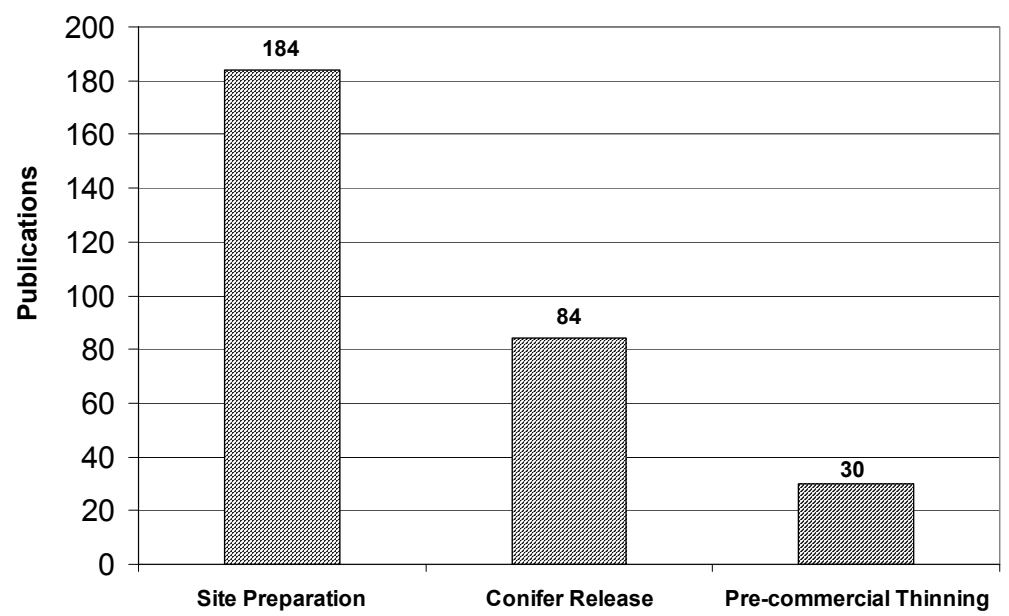

B. Sub-Topics

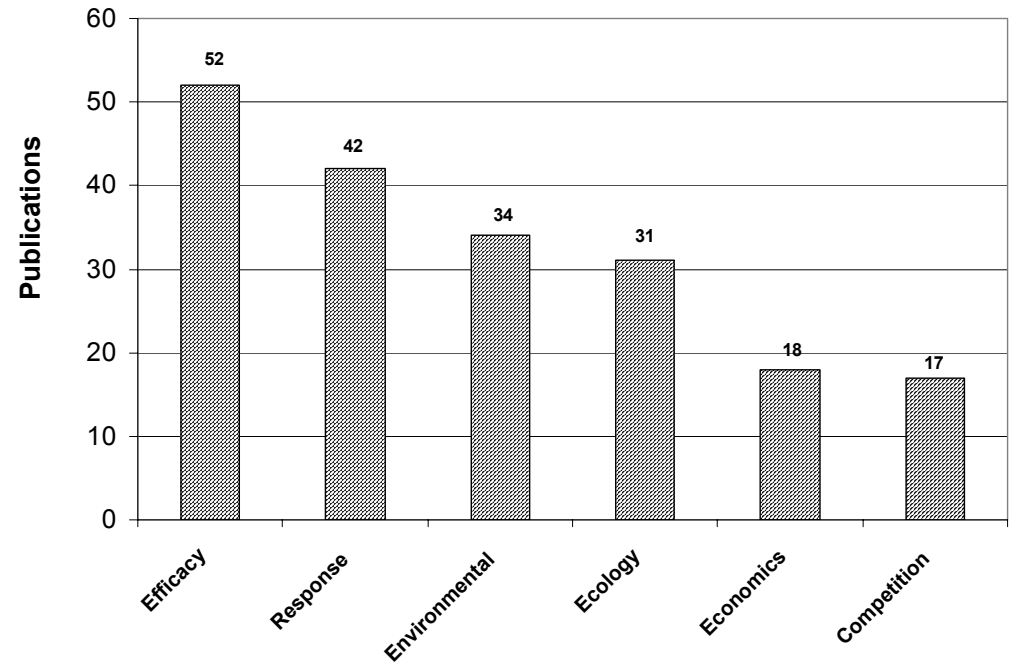

Figure 8. Number of journal publications pertaining to vegetation management in Canada (1990-present) in relation to (A) management strategy or (B) sub topic focus. that time frame has been on site preparation $(62 \%)$, with relatively fewer studies on conifer release $(28 \%)$ or pre-commercial thinning (10\%) strategies (Fig. 8a). Research has been relatively evenly distributed across sub-topics of efficacy, crop response and environmental effects, with relatively few studies examining economic aspects (Fig. 8b). Of papers classified as documenting environmental effects of forest vegetation management practices in Canada since 1990, almost all were studies investigating the environmental fate and effects of chemical herbicides [29, 65, 69, 76, 77, 79] and several were generated by a major multidisciplinary study conducted in northwestern Ontario [45, 66, 79]. Very few studies were conducted on the potential environmental effects of other vegetation management techniques.

Canadian research publications reflect the predominance of chemical and mechanical techniques in operational use patterns (Fig. 9). As might be expected, the majority of publications (352/358) relating to chemical methods involved glyphosate (Vision ${ }^{\circledR}$ ), with environmental fate and effects assessments and medium-term ( 10 years) efficacy studies predominanting. Publications relating to silivicultural techniques were dominated by studies on thinning, prescribed fire, and environmental assessment of alternative harvesting techniques in relation to clearcutting $[23,51]$. Publications on other methods, such as biological control, have been few and resulted largely from targeted research programs such as the Vegetation Management Alternatives Program (VMAP) [84] and the related federal BICOVER network initiative [80].

Vegetation management research has been primarily centered on key high quality coniferous crop species groups including fir, pine, cedar and hemlock (Fig. 10a) and targeted at key competitors including particularly Populus, Alnus and Rubus spp. (Fig. 10b). Unfortunately, the vast majority of crop response data resulting from Canadian research is derived from relatively short term $(<10 \mathrm{yr}$ studies $)$, with progressively fewer studies providing data over the (10-24 yr) and long ( $>25$ term (Fig. 10c). No data derived from observations made over a full rotation cycle is yet available. 


\section{Control Techniques}



Figure 9. Number of journal publications pertaining to vegetation management in Canada (1990-present) in relation to focus on various control techniques.
Significant positive growth responses (height and diameter) in a variety of conifer crops following various site preparation or release treatments have been demonstrated in both short- [57, $60,61,87]$ and medium-term studies [10, 62, 94]. Although data supporting similar growth effects over the long term are scarce, at least one study [70] demonstrates that positive effects continue through a period of 30 years in white spruce. Other studies illustrate dramatic declines in juvenile conifer dominance with the absence of treatment $[9,60-62]$. While these studies are based on relatively short-term data, it is unlikely that such trends will reverse themselves without silvicultural intervention.

Not surprisingly, publications relating to vegetation management research in Canada were largely derived from provinces traditionally known for forest production including, in order, British Columbia, Ontario and Quebec, and the number of papers providing information pertinent to particular forest regions is roughly proportional to the size of each of the major Canadian forest regions, with the vast area of the boreal forest predominating. Studies focused on vegetation management in non-traditional crop-secies such as hybrid poplar [73] were not numerous.

\section{DISCUSSION}

\subsection{Current status assessment}

Results suggest that over the past decade, important advances in research and practice have been made. Research programs have been appropriately focused on key target and crop species, and have generated an increasing knowledge base supporting the principal operational techniques used in forest vegetation management across the nation. A number of papers directly pertinent to forest vegetation management conditions in Canada have enhanced knowledge in basic sub-disciplines of critical silvics, ecophysiology, and plant autecology [15, 33, $34,48]$, as well as competition mechanisms and critical competitive thresholds $[7,67,71,82,87]$.

Several innovative approaches and techniques for controlling competing vegetation, or off-setting resultant losses in growth of crop trees, have been developed and reported since 1990. These include the application of plant growth regulators for enhanced stocking success and seedling growth in Douglas fir (Pseudotseuga menziesii (Mirb.) Franco) [64], nutrient loading of black spruce seedlings to reduce competitive effects $[38,39,48]$, and development of Chondrostereum purpureum as a biological control agent. An extensive knowledge base relating to this fungal pathogen and its potential use for control of re-sprouting woody competitor species has been generated $[30,35,40,59,88,89]$. This scientific knowledge base has been key to the recent registration of Myco-Tech Paste ${ }^{\mathrm{TM}}$ (Myco-Forestis Corp.) as the first commercial biocontrol agent for forestry in Canada [58], as well as a pending application for registration of a second product based on this same fungal organism. Development and registration of this biocontrol agent represents a major breakthrough, particularly in the province of Quebec, where herbicide use in forestry has been banned. However, a limited efficacy spectrum and application technology issues have constrained operational use to date. Recent innovations have purportedly overcome these limitations (B. Ure 2003, personal communication). In contrast, the use of nutrient loaded stock has become a common operational practice in many regions. However, the degree to which other approaches and technologies become incorporated into industrial programs remains to be seen.

Trend data indicating that $75-80 \%$ of harvested forest lands have been successfully regenerated and that an increasing proportion of the area is free from non-crop competition (Fig. 4), suggests that operational vegetation management techniques have generally been successful. However, successful regeneration should consider not only stocking levels and competition, but also the need to match species to site. Lack of attention to this aspect has led to substantive changes in species composition in the boreal forests of northern Ontario, where spruce has been replaced by increased hardwood components in many second growth forests $[13,36]$.

At a finer level of resolution, several vegetation management problems remain unsolved and there is a general tendency toward curative as opposed to preventative approaches. 
A. Major Coniferous Crop Species

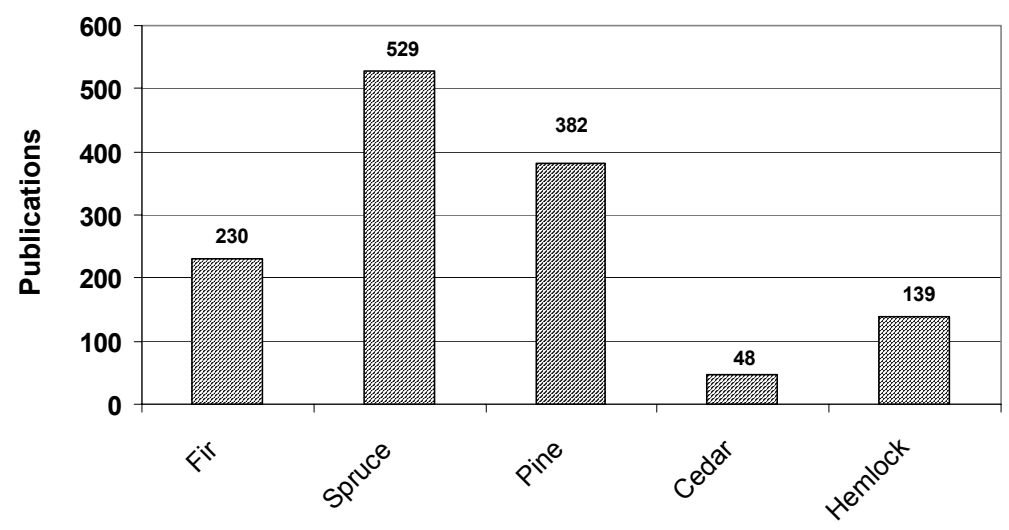

C. Observation Period



C. Observation Period

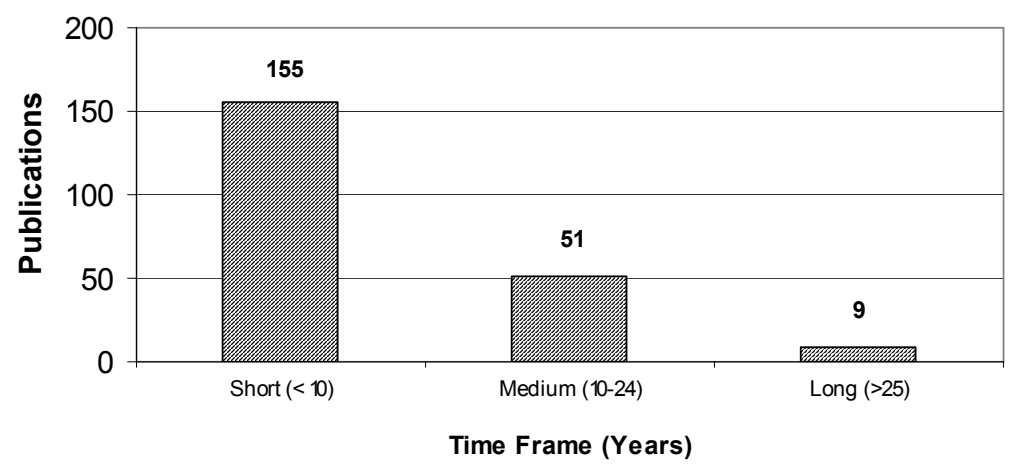

Figure 10. Number of journal publications pertaining to vegetation management in Canada (1990-present) in relation to (A) major crop species, (B) major competitor species or (C) observation period.
In addition, further optimization of many conventional practices may be possible. For example, although the chemical release program is cost-effective and efficacious, it is reliant on essentially one compound (glyphosate). Few alternative herbicides are available and, with the exception of an attempted minor use registration for imazapyr, we know of none that are under development for forestry. Despite many years of herbicide applications for forest vegetation management, there is still much to be learned with regard to optimum timing [5] and the extent and duration of weed control required to meet silvicultural objectives on specific site types [7]. More efficient methods of herbicide application have also been identified as a requirement, particularly for ground-based techniques and in relation to advanced methods of aerial application using electronic guidance systems for optimal control and targeted delivery of the chemical to the site. Practitioners of forest vegetation management often identify a need for changes in legislation to allow for the use of tank mixtures [7] as an efficient means of controlling competing vegetation complexes such as Rubus/Calamagrostis/Epilobium, or for use in vegetation management in deciduous crop tree and mixedwood silvicultural systems. 
As many of the key competitor species in Canada (Tab. I) resprout vigorously from stems, underground rhizomes, and/or root stocks, use of manual and mechanical techniques often exacerbate competition problems or require repetitive applications which can be cost-prohibitive. In the pursuit of alternatives to chemical herbicides, substantial effort has been expended on increasing our understanding of manual cutting efficacy [4] and optimizing efficacy based on the season and timing of cutting [6].

The potential to minimize post-harvest vegetation problems from developing by employing certain preventative preharvest, harvest, and site-preparation measures has been discussed for years [90]. In practice to date, many of these measures ultimately have little effect on competition-prone sites and, as a result, trends in Canada have leaned away from site preparation and early intervention, with relatively little research and development effort expended to explore preventative approaches such as alternative harvesting methods and larger stock (Fig. 8). Moreover, there is a distinct need for development and demonstration of effective intensive management strategies that integrate a number of techniques, either concomitantly or through time, to maximize growth response and productivity of key high value crop species on quality sites. Wagner et al. $[82,87]$ and $[60-62]$ have demonstrated that early and sustained intervention to control herbaceous competition yields substantial increases in stem diameter and volume of several coniferous crop species. Jobidon et al. [41] and Thiffault et al. [72] have also demonstrated the benefits of early release from competition and, at least in some cases, a multiplicative effect of vegetation control when combined with planting of larger stock [41]. Although such intensive vegetation management approaches are commonly employed in other countries such as the USA, New Zealand and Australia, vegetation management in Canada has largely been restricted to either a single site preparation or release treatment on any given site, usually focusing on overtopping woody competition. Neither of these approaches would generally be expected to yield maximal crop growth response or economic benefits.

Several independent studies that document significant crop growth response benefits resulting from applications of glyphosate $\left(\right.$ Vision $\left.^{\circledR}\right)$ support the continued use of this product in terms of increased growth response in various crops and relative to other vegetation control methods including brushsaw, and triclopyr basal bark treatments in jack pine [61], polyethylene mulch mats in hybrid poplar [74], manual cutting in black spruce [42] and repeated mechanical cutting in Englemann spruce (Picea engelmannii Parry ex Engelm.) [21]. However, as is the case for essentially all crop growth response data in Canada, these study results are short-term $(<10 \mathrm{yrs})$ in nature and may not accurately reflect treatment benefits to be expected at full rotation. In fact, some studies yield conflicting conclusions as to whether such crop growth responses to early vegetation management treatments translate into significant increases in total stand volume at longer time frames (i.e., $1 / 2$ to full rotation age). Differentiation must now be made between objectives surrounding the maintenance of conifer-dominated ecosystems and those pertaining strictly to fibre production.

In this regard, a concerted effort is necessary to identify, maintain and re-measure previously established research plots and to establish permanent research sites with the potential to address these and other long-term data requirements. While some long-term study sites have been established (e.g. Carnation Creek, Cowichan Lake and MASS study sites in British Columbia [12], Fallingsnow Site in Ontario [45]), the commitment and funding support to these is often tenuous. Moreover, although long-term studies are recognized as having substantial potential for effects on forest management policy (BCMOF 2001), there has been no coordinated strategic planning at the national level to ensure that appropriate sites, representative of the major forest regions in Canada, are selected for comparative, long-term, vegetation management studies. We suggest that multi-disciplinary studies covering larger spatial scales and longer time frames, which include comparative assessments of new approaches against current industry standards and concomitant evaluations of efficacy, crop response economics and environmental effects at higher levels of biological organization (population, stand or ecosystem level), are required to advance science in this area.

Further, detailed economic analyses required to support the need for and benefits of various vegetation management strategies and techniques are scarce in Canada. As noted by [54], benefit-cost analysis is generally considered the most suitable method for evaluation but may yield different results when considered at the stand and forest levels. In their example for a hypothetical jack pine forest in Ontario, an option involving heavy site preparation, planting of container stock, and aerial herbicide application resulted in a benefit-cost ratio of 5.76 and an estimated net present value of $10055 \$ / \mathrm{ha}$, compared to $4721 \$$ /ha for natural regeneration which was the second highest value among five other management options examined. The paucity of detailed economic analyses is surprising, given the necessary industrial focus on costs and return on investments [2] and undermines our ability to convince skeptical forest managers, forest certification auditors, and the public of the benefits of vegetation management in Canadian forestry.

In summary, while Canadian forest vegetation management research and practice have been generally successful, there are shortcomings including:

(i) reliance on curative chemical and mechanical methods as opposed to more preventative techniques such as the use of alternative stocking or harvesting methods,

(ii) reliance on relatively late release rather than early intervention approaches, including site preparation,

(iii) reliance on a single chemical herbicide (glyphosate),

(iv) a paucity of data clearly demonstrating long-term growth response and economic benefits.

\subsection{Key factors influencing the future of vegetation management in Canada}

In addition, to the land tenure system [93] and differential provincial management policies, which directly or indirectly influence Canadian forest management generally, there are several other national and international factors that may be postulated to interact and force change in Canadian forest vegetation management over the next decade. These factors include:

Increased use of alternative harvesting techniques - although clearcutting has and will probably remain the predominant 
silvicultural system in Canada for the foreseeable future, continued national and international opposition to this practice is beginning to induce change. For example, the Weyerhauser Corporation in British Columbia has committed to discontinue clear-cutting on their coastal forest land holdings in favor of "variable-retention harvesting". In Ontario, increasing use is being made of "careful logging around advanced growth" and similarly in Quebec, "cutting with protection of regeneration and soils" was mandated by the Forest Act. An approximate $60 \%$ increase in use of this use of careful logging has occurred on the area harvested under even-aged management on Crown lands between 1987 and 1999 [19]. Changes in harvesting practices may be expected to alter the degree of canopy opening, soil disturbance and microclimate - all of which are primary drivers influencing the vegetative community re-occupying a site. Hence, any change to harvesting practices may induce concomitant changes in both the species mixture and intensity of vegetation competing for limiting resources. The few studies which compare succession following alternative harvesting [44, 46, 49], associated vegetation management requirements $[32,47]$ and crop productivity $[43,47,50]$, suggest that in some cases alternative harvesting practices could minimize the intensity of competition and resultant need for vegetation management incursions, at least within some site types.

However, as noted by Dey and MacDonald [24], techniques such as shelterwood harvesting without proper preparation of the seedbed and control of competing vegetation often result in regeneration failures. Recent studies investigating vegetative response to uniform shelterwood harvesting techniques in Alberta demonstrate some reduction in raspberry and poplar competition, but very little impact on Calamagrostis canadensis grass. Similarly, we have observed trembling aspen to remain a serious competitor in the understory of Ontario white pine (Pinus strobus L.) shelterwood cuts, despite more than $50 \%$ crown closure in the overstory. We have also observed some recent "variable retention harvests" that amount to little more than complete removals of the merchantable stems and retention of the low quality stems and less merchantable species. There is neither the operational experience nor scientific understanding available to deal with the vegetation management problems that are likely to ensue from such activities. Moreover, recent studies [37] predict that some alternative harvesting techniques such as group selection cutting may result in increased soil losses over those induced by clearcutting. Such observations emphasize the need for full comparative evaluations of the efficacy, cost-effectiveness and environmental impacts associated with any potential sequence of silvicultural events. Thus, while alternative harvesting may be useful on some sites, it is unlikely to be the "silver bullet" for competing vegetation problems generally and in many cases may simply induce a shift to a different set of competitive interactions and challenges for researchers and practitioners alike.

Commercial and non-commercial use of species historically considered as weeds - may restrict the application of vegetation management techniques in some areas. In particular, new mills or milling policies have been established to take advantage of the widespread and rapid growth of species such as trembling aspen, previously considered strictly as problematic competitors, resulting in reduced regional demand for vegetation competition control. While aspen culture may be important in some areas, particularly for production of oriented strand board products, high quality conifer production will undoubtedly remain as Canada's key international forest product market niche and the maintenance of conifer habitat will always be a priority. Thus, it is critical that programs of research and practice maintain focus on integrated vegetation management techniques for enhancing growth and production of high quality conifer crops.

The introduction of exotic competitors may also provide Canadian vegetation management specialists with new challenges. As with many of our native pioneer "weedy" species, exotic plant species such as scotch broom (Cytisus scoparius) and gorse (Ulex europaeus) are also well adapted to highly disturbed conditions such as roadsides, providing them a foothold for further expansion in to the Canadian forest landbase. The potential for these species to become serious new competition problems, particularly in Western Canada, has recently been noted [20] and rapid action to curtail expansion is recommended. Adopting expertise available from international research colleagues and practitioners intimately familiar with these problem species is an obvious first step to controlling these and other potential exotic problems.

Increasing segregation and protection of forest lands are expected to continue, further diminishing the forest area available for timber, pulp, and paper production. This process is already well underway. In 1995, approximately $7.6 \%$ (roughly 32 million hectares) of Canada's forest land was protected by legislation. Since that time, many provinces have increased the number and size of protected areas. For example, in Ontario, the Ontario Forest Accord resulted in the creation of 378 new parks and protected areas, enhancing previously protected areas by more than 2.4 million hectares. As part of this accord, forest industry, environmentalists and the public have agreed that overall production rates and wood supply to mills will not be constrained [56]. Avoiding a wood supply limitation requires development of truly integrated silviculural strategies and greater production from less area in less time [3]. In the short term, these needs are expected to be met largely by increased commercial thinning. In the longer term, intensive vegetation management applied to high quality sites may also help to offset wood supply problems and focus efforts on those areas with greatest potential economic benefit [11]. Indirectly, intensive management on these selected smaller portions of the landbase could result in an overall reduction of human intervention and environmental impacts on the broader forest landscape [8] and may be viewed as a positive development from an environmental perspective as well.

Biotechnology research has the potential to modify forest vegetation management in the future, particularly through the development of herbicide-resistant tree species, in a manner parallel to developments in the agricultural sector. However, as for any vegetation control technique or other anthropogenic disturbance to natural systems, use of these biotechnologies carry potential risks for adverse environmental effects [92] and may be considered unacceptable by some Canadian public landowners as has previously been demonstrated for other novel vegetation control technologies [86]. While opposition to such biotechnology in the agricultural sector appears to be lower in North America as compared to Europe [28], we anticipate 
that substantial public opposition will continue to constrain practical realization of these potentials in the Canadian forestry sector.

Forest certification is considered to be a powerful indirect economic incentive influencing forest vegetation management practice in Canada. According to a recent status report [1] approximately $95 \%$ of Canada's 119 million hectares of managed forest lands have been certified under various 3rd party certification standards. The high degree of forest certification demonstrates a strong industry commitment to sustainable forestry and intent to meet client demands.

Targeted government research programs - Some examples in the last decade include the federal Green Plan, Forest Renewal BC, the Ontario Vegetation Management Alternatives Program, and the Ontario Forest Accord. The latter is in its initial stages and reflects a general trend wherein a greater proportion of the forested landbase is being allocated to parks or conservation areas in an effort to enhance biodiversity, aesthetic and recreational values, while more intensive forestry is conducted on the reduced commercial forest landbase, to ensure sustainable timber, pulp and paper production. The Ontario Forest Accord and related Living Legacy Trust have forged innovative partnerships among governments, environmentalists, communities and resource industries, enhancing investment in vegetation management research and altering the approach to natural resources management generally. Many consider this an excellent model which has already and will continue to accelerate research, development and innovation in vegetation management research and practice as well as forest management generally.

\section{CONCLUSIONS}

Substantial progress has been made in Canadian forest vegetation management research over the last decade and operational programs focused largely on mechanical site preparation and applications of glyphosate for conifer release have been critical to the successful regeneration of major forest crop species in Canada. Despite these advances and general operational success, previous calls (e.g., FRACC 1992; [80]) to reduce our dependence on mechanical site preparation and release with a single chemical herbicide have not been fully met. Both the research community and industry practitioners are responding to new demands and opportunities associated with a decreasing commercial forest land base, international forest certification, new scientific discoveries, and alternative harvesting practices now coming into vogue. New research initiatives should include a balanced focus on preventative rather than curative strategies, alternatives to mechanical site preparation and chemical release, and development of holistic vegetation management techniques that are consistent and integrated with other silvicultural activities over the entire rotation cycle. Research and development of a full suite of vegetation management techniques and strategies that are demonstrably costeffective, efficacious and environmentally acceptable to international standards will be important in continued evolution of a knowledge-based, integrated, and sustainable forest management [55], ensuring a continuous supply of quality forest products to Canadian mills with minimal deleterious effects on the multiple values associated with our forest ecosystems.
Acknowledgements: The authors wish to thank Drs. H. Frochot C. Collet and P. Balandier for organizing the 4th International Conference on Forest Vegeation Management and the invitation to prepare this paper for the conference. We also wish to thank Lisa Verkley for her assistance in preparation of the manuscript as well as M. Mihajlovich and two anonymous reviewers for their valuable suggestions in improving the manuscript.

\section{REFERENCES}

[1] Abusow K., Canadian forest management certification status report. Status report prepared for the Canadian Sustainable Forestry Certification Coalition, Abusow International, Ottawa ON, 2002, p. 8.

[2] Bell F.W., Buse L.J., Wagner R.G., Lautenschlager R.A., Neal J.C., Factors that promote or limit the use of vegetation management alternatives by forest managers in Ontario, Proceedings of the forty-ninth annual meeting of the Northeastern Weed Science Society, Boston, MA, 1995, pp. 96-97.

[3] Bell F.W., Pitt D.G., Irvine M., Parker W.C., Buse L.J., Stocker N., Towill W.D., Chen H., Pinto F., Brown K., DeYoe D., McDonough T., Smith G., Weber M., Intensive forest management in Ontario: Summary of a 1999 science workshop, Ontario Ministry of Natural Resources, Sault Ste. Marie, Ontario, 2000.

[4] Bell F.W., Lautenschlager R.A., Wagner R.G., Pitt D.G., Hawkins J.G., Ride, K., Motor-manual, mechanical, and herbicide release affect early successional vegetation in northwestern Ontario, For. Chron. 73 (1997) 61-68.

[5] Bell F.W., Pitt D.G., Mallik A.U, Hollstedt H., Seasonal Susceptibility of Boreal Plants to Glyphosate I: Blue-Joint Grass and Black Spruce, North. J. Appl. For. 17 (2000) 141-148.

[6] Bell F.W., Pitt D.G., Morneault A., Pickering S., Response of immature trembling aspen to season and height of cut, North. J. Appl. For. 16 (1999) 108-114.

[7] Bell F.W., Ter-Mikaelian M.T., Wagner R.G., Relative competitiveness of nine early-successional boreal forest species associated with planted jack pine and black spruce seedlings, Can. J. For. Res. 30 (2000) 790-800.

[8] Binkely C.S., Preserving nature through intensive plantation forestry: The case for forest land allocation with illustrations from British Columbia, For. Chron. 73 (1997) 553-559.

[9] Biring B.S., Comeau P.G., Fielder P., Long-term effects of vegetation control treatments for release of Engelmann spruce from a mixed-shrub community in Southern British Columbia, Ann. Sci. For. 60 (2003) 681-690.

[10] Biring B.S., Hays-Byl W.J., Hoyles S.E., Twelve-year conifer and vegetation responses to discing and glyphosate treatments on a BWBSmw backlog site., Working Paper, Ministry of Forests Research Program, British Columbia. No. 43, 1999, 34 p.

[11] Brett P., Benskin H., Guidelines for cost-effective intensive forest management in B.C., Pulp and Pap. Can. 79 (1978) 66-68.

[12] British Columbia Ministry of Forests - Forest Science Program Annual Report 2000/2001, British Columbia, Ministry of Forests, Research Branch, 2001, p. 53.

[13] Burgess D., Larocque G.R., Brand D.G., Forest growth and future yields: The importance of today's regeneration practices, in: Wagner R.G., Colombo S.J. (Eds.), Regenerating the Canadian forest - principles and practice for Ontario, Fitzhenry \& Whiteside Limited, Markham, ON, 2001, pp. 604-624.

[14] Buse L.J., Bell F.W., Critical silvics of selected crop and competitor species in northwestern Ontario, Northwestern Ontario Forest Technology Development Unit, Thunder Bay, Ontario, 1992, $138 \mathrm{p}$.

[15] Campbell R.A., Herbicide use for forest management in Canada: where we are and where we are going, For. Chron. 66 (1990) 335360. 
[16] Campbell R.A., Silvicultural herbicides in Canada: registration status and research trends, For. Chron. 67 (1991) 520-527.

[17] Campbell R.A., Howard K.M., Priorities for forestry herbicide application technology research, Can. J. For. Res. 23 (1993) 2204 2212.

[18] Campbell R.A., Wood J.E., Thompson D.G., Iskra E., Site preparation - chemical, in: Wagner R.G., Colombo S.J. (Eds.), Regenerating the Canadian forest - principles and practice for Ontario, Limited, Markham, ON, 2001, pp. 221-239.

[19] Canadian Council of Forest Ministers, National Forestry Database Program, 2002, http://nfdp.ccfm.org/

[20] Clements D.R., Peterson D.J., Prasad R., The biology of Canadian weeds, 112, Ulex europaeus L., Can. J. Plant Sci. 81 (2001) 325337.

[21] Comeau P.G., Biring B.S., Harper G.J., Effectiveness of repeated manual cutting and glyphosate for release of Engelmann spruce from mixed-shrub herb vegetation, Western J. Appl. For. 15 (2000) 154-162.

[22] Comeau P.G., Biring B.S., Harper G.J., Conifer response to brushing treatments: a summary of British Columbia data, Extension Note, British Columbia Ministry of Forests, 1999, No. 41,12 p.

[23] de Bellefeuille S., Belanger L., Huot J., Cimon A., Clear-cutting and regeneration practices in Quebec boreal balsam fir forest: effects on snowshoe hare, Can. J. For. Res. 31 (2001) 41-51.

[24] Dey D.C., MacDonald G.B., Overstorey manipulation, in: Wagner R.G., Colombo S.J. (Eds.), Regenerating the Canadian forest principles and practice for Ontario, Fitzhenry \& Whiteside Limited, Markham, ON, 2001, pp. 157-175.

[25] Dunster J., Dunster K., Dictionary of Natural Resource Management, UBC Press, University of British Columbia, Vancouver, British Columbia, 1996.

[26] Erdle T.A., The conflict in managing New Brunswick's forests for timber and other values, For. Chron. 75 (1999) 945-954.

[27] Forest Research Advisory Council of Canada, Forest Research Priorities in Canada, 1991, For. Chron. 68 (1992) 121-125.

[28] Gaskell G., Bauer M.W., DuRant J., Allum N.C., Worlds apart? The reception of genetically modified foods in Europe and the U.S., Science 285 (1999) 384-387.

[29] Goldsborough L.G., Brown D.J., Dissipation of glyphosate and aminomethylphosphonic acid in water and sediments of boreal forest ponds, Environ. Toxicol. Chem. 12 (1993) 1139-1147.

[30] Gosselin L., Jobidon R., Bernier L., Genetic variability and structure of Canadian populations of Chondrostereum purpureum, a potential biophytocide, Molecular Ecol. 8 (1999) 113-122.

[31] Government of Canada, Action plans of the federal government in response to the National Forest Strategy (1998-2003) - Sustainable Forests: A Canadian Commitment, 1999.

[32] Groot A., Effects of shelter and competition on the early growth of planted white spruce (Picea glauca), Can. J. For. Res. 29 (1999) 1002-1014.

[33] Grossnickle S.C., Parker W.C., Blake T.J., Sutton R.F., Ecophysiological principles, in: Wagner R.G., Colombo S.J., (Eds.), Regenerating the Canadian forest - principles and practice for Ontario, Fitzhenry \& Whiteside Limited, Markham, ON, 2001, pp. 91-118.

[34] Haeussler S., Coates D., Mather J., Autecology of common plants in British Columbia: a literature review, FRDA Report Victoria, British Columbia, No. 158, 1990, vi + 272 p.

[35] Harper G.J., Comeau P.G., Hintz W., Wall R.E., Prasad R., Becker E.M., Chondrostereum purpureum as a biological control agent in forest vegetation management. II. Efficacy on Sitka alder and aspen in western Canada, Can. J. For. Res. 29 (1999) 852-858.

[36] Hearnden K.W., Millson S.V., Wilson W.C., A report on the status of forest regeneration, Ontario Ministry of Natural Resources, 1992, p. 117.
[37] Hood S.M., Zedaker S.M., Aust W.M., Smith D.W., Universal soil loss equation (USLE) predicted soil loss for harvesting regimes in Appalachian hardwoods, North. J. Appl. For. 19 (2002) 53-58.

[38] Imo M., Timmer V.R., Vector competition analysis of black spruce seedling responses to nutrient loading and vegetation control, Can. J. For. Res. 29 (1999) 474-486.

[39] Imo M., Timmer V.R., Growth and nitrogen retranslocation of nutrient loaded Picea mariana seedlings planted on boreal mixedwood sites, Can. J. For. Res. 31 (2001) 1357-1366.

[40] Jobidon R., Comparative efficacy of biological and chemical control of the vegetative reproduction in Betula papyrifera and Prunus pensylvanica, Biol. Conserv. 11 (1998) 22-28.

[41] Jobidon R., Roy V., Cyr G., Net effect of competing vegetation on selected environmental conditions and performance of four spruce seedling stock sizes after eight years in Quebec (Canada), Ann. For. Sci. 60 (2003) 691-699.

[42] Jobidon R., Trottier F., Charette L., Chemical or manual weed control in black spruce plantations? Case study in the balsam fir white birch [ecosystem] in Quebec, For. Chron. 75 (1999) 973 979.

[43] Jull M.J., Stevenson S.K., The Lucille Mountain study: 8-year results of a silvicultural systems trial in the Engelmann SpruceSubalpine Fir zone, Working Paper, Ministry of Forests Research Program, British Columbia, No. 59, 2001, x + 93 p.

[44] Lafleche V., Ruel J.C., Archambault L., Evaluation of logging with protection of regeneration and soil as a method of regenerating mixed wood stands in the bioclimatic zone of balsam fir and yellow birch in eastern Quebec, For. Chron. 76 (2000) 653-663.

[45] Lautenschlager R.A., Bell F.W., Wagner R.G., Reynolds P.E., The Fallingsnow Ecosystem Project: documenting the consequences of conifer release alternatives, J. For. 96 (1998) 20-27.

[46] Lieffers V.J., Macmillan R.B., MacPherson D., Branter K., Stewart J.D., Semi-natural and intensive silvicultural systems for the boreal mixedwood forest, For. Chron. 72 (1996) 286-292.

[47] MacDonald G.B., Harvesting boreal mixedwood stands to favour conifer regeneration: project establishment and early results, Fores Research Report, Ontario Forest Research Institute, No. 157, 2000, $20 \mathrm{p}$.

[48] Malik V., Timmer V.R., Growth, nutrient dynamics, and interspecific competition of nutrient-loaded black spruce seedlings on a boreal mixedwood site, Can. J. For. Res. 26 (1996) 1651-1659.

[49] Maynard D.G., MacIsaac D.A., Krause H., Soil nutrient and vegetation response to patch clear-cutting of an aspen forest near Meadow Lake, Saskatchewan, Sustainable site productivity in Canadian forests workshop, Sault Ste. Marie, Ontario, February 1997, Can. J. Soil Sci. 78 (1998) 59-68.

[50] Mitchell A.K., Growth limitations for conifer regeneration under alternative silvicultural systems in a coastal montane forest in British Columbia, Canada, For. Ecol. Manage. 145 (2001) 129136.

[51] Moses R.A., Boutin S., The influence of clear-cut logging and residual leave material on small mammal populations in aspendominated boreal mixedwoods, Can. J. For. Res. 31 (2001) 483495.

[52] Natural Resources Canada, Silvicultural terms in Canada (2nd ed.), Policy, economics and International Affairs Directorate, Canadian Forest Service, Natural Resources Canada, Ottawa, Canada, 1995, p. 109.

[53] Natural Resources Canada, State of Canada's Forests Report, 1999-2000, http://www.nrcan.gc.ca:80/cfs/pub/pub_e.html, Forests in the new millenium, 2000.

[54] Nautiyal J.C., Williams J.S., Innes M.R., Gravelines L., Ghebremichael A., Financial Evaluation, in: Wagner R.G., Colombo S.J. (Eds.), Regenerating the Canadian forest - principles and practice for Ontario, Fitzhenry \& Whiteside Limited, Markham, ON, 2001, pp. 589-602. 
[55] Oliver C.D., The future of the forest management industry: Highly mechanized plantations and reserves or a knowledge-intensive integrated approach? For. Chron. 75 (1999) 229-245.

[56] Ontario Ministry of Natural Resources, 1999 Ontario Forest Accord - A foundation for progress, Queen's Printer for Ontario, Toronto, Canada, 1999, $136 \mathrm{p}$.

[57] Perie C., Munson A.D., Ten-year responses of soil quality and conifer growth to silvicultural treatments, Soil Sci. Soc. Am. J. 64 (2000) 1815-1826.

[58] Pest Management Regulatory Agency (PMRA) - Health Canada, Proposed regulatory decision document PRDD2002-01, 2002, p. 30.

[59] Pitt D.G., Dumas M.T., Wall R.E., Thompson D.G., Lanteigne L., Hintz W., Sampson G., Wagner R.G., Chondrostereum purpureum as a biological control agent in forest vegetation management. I. Efficacy on speckled alder, red maple, and aspen in eastern Canada, Can. J. For. Res. 29 (1999) 841-851.

[60] Pitt D.G., Krishka C.S., Bell F.W., Lehela A., Five-year performance of three conifer stock types on fine sandy loam soils treated with hexazinone, North. J. Appl. For. 16 (1999) 72-81.

[61] Pitt D.G., Morneault A.E., Bunce P., Bell F.W., Five years of vegetation succession following vegetation management treatments in a jack pine ecosystem, Nor. J. Appl. For. 17 (2000) 100-109.

[62] Pitt D.G., Wagner R.G., Towill W.T., Ten years of vegetation succession following ground-applied release treatments in young black spruce plantations, North. J. Appl. For. (in press).

[63] Ryans M., Sutherland B., Site preparation - mechanical, in Wagner R.G., Colombo S.J. (Eds.), Regenerating the Canadian forest - principles and practice for Ontario, Fitzhenry \& Whiteside Limited, Markham, ON, 2001, pp. 177-199.

[64] Scagel C.F., Linderman R.G., Modification of root IAA concentrations, tree growth, and survival by application of plant growth regulating substances to container-grown conifers, New For. 21 (2001) 159-186.

[65] Sidhu S.S., Feng J.C., Hexazinone and its metabolites in boreal forest vegetation, Weed Sci. 41 (1993) 281-287.

[66] Simpson J.A., Gordon A.M., Reynolds P.E., Lautenschlager R.A., Bell F.W., Gresch D.A., Buckley D.A., Influence of alternative conifer release treatments on soil nutrient movement, Fallingsnow Ecosystem Project, For. Chron. 73 (1997) 69-73.

[67] Staples T.E., van Rees K.C.J., van Kessel C., Nitrogen competition using $15 \mathrm{~N}$ between early successional plants and planted white spruce seedlings, Can. J. For. Res. 29 (1999) 1282-1289.

[68] Statistics Canada, Statistics Canada's Internet Site, 2000, Data extracted 08/2000, http://www.statcan.ca.

[69] Sullivan T.P., Wagner R.G., Pitt D.G., Changes in diversity of plant and small mammal communities after herbicide application in subboreal spruce forest, Can. J. For. Res. 28 (1998) 168-177.

[70] Sutton R.F., White spruce establishment: initial fertilization, weed control and irrigation evaluated after three decades, New For. 9 123-133.

[71] Ter-Mikaelian M.T., Wagner R.G., Bell F.W., Shropshire C., Comparison of photosynthetically active radiation and cover estimation for measuring the effects of interspecific competition on jack pine seedlings, Can. J. For. Res. 29 (1999) 883-889.

[72] Thiffault N., Jobidon R., Munson A.D., Performance and physiology of large containerized and bare-root spruce seedlings in relation to scarification and competition in Québec (Canada), Ann. For. Sci. 60 (2003) 645-655.

[73] Thomas K.D., Comeau P.G., Brown K.R., The silviculture of hybrid poplar plantations, Extension Note, British Columbia Ministry of Forests, No. 47, 2000, 7 p.

[74] Thomas K.D., Reid W.J., Comeau P.G., Vegetation management using polyethylene mulch mats and glyphosate herbicide in a coastal British Columbia hybrid poplar plantation: four-year growth response, West. J. Appl. For. 16 (2001) 26-30.
[75] Thompson D.G., Holmes S.B., Verkley L.M., Canadian Forest Pest Management Database, 2001, http://www.glfc.cfs.nrcan.gc.ca/cfpm

[76] Thompson D.G., Kreutzweiser D.P., Capell S.S., Thomas D.R., Staznik B., Viinikka T., Fate and effects of triclopyr ester in a firstorder forest stream, Environ. Toxicol. Chem. 14 (1995) 13071317.

[77] Thompson D.G., Pitt D.G., Buscarini T.M., Staznik B., Thomas D.R., Comparative fate of glyphosate and triclopyr herbicides in the forest floor and mineral soil of an Acadian forest regeneration site, Can. J. For. Res. 30 (2000) 1808-1816.

[78] Thompson D.G., Pitt D.G., Campbell R.A., Herbicides and forestry - The scientific perspective, Forestry on the Hill - Special Issue on Herbicides and Forestry 5 (1991) 53-59.

[79] Thompson D.G., Pitt D.G., Staznik B., Payne N.J., Jaipersaid D., Lautenschlager R.A., Bell F.W., On-target deposit and vertical distribution of aerially released herbicides, For. Chron. 73 (1997) $47-59$.

[80] Thompson D.G., Watson A.K., Dorworth C., Dumas M., Strunz G., Jobidon R., Harris P., Castello J., Wagner R., BICOVER - A national research network on biological control of competing vegetation, Proceedings of the 1st International Weed Control Congress 2 (1992) 522-526.

[81] Wagner R.G., Research directions to advance forest vegetation management in North America, Can. J. For. Res. 23 (1993) 2317 2327.

[82] Wagner R.G., Competition and critical-period thresholds for vegetation management decisions in young conifer stands, For Chron. 76 (2000) 961-968.

[83] Wagner R.G., Bell F.W., Campbell R.A., Vegetation management, in: Wagner R.G., Colombo S.J. (Eds.), Regenerating the Canadian forest - principles and practice for Ontario, Fitzhenry \& Whiteside Limited, Markham, ON, 2001, pp. 431-458.

[84] Wagner R.G., Buse L.J., Lautenschlager R.A., Bell F.W., Hollstedt C., Strobl S., Morneault A., Lewis W., Ter-Mikaelian M.T., Vegetation Management Alternatives Program 1994-95 Annual Report, Ontario Ministry of Natural Resources, Queen's Printer for Ontario, 1995, p. 99.

[85] Wagner, R.G., Colombo S.J., Regenerating the Canadian forest principles and practice for Ontario, Fitzhenry \& Whiteside Limited, Markham, ON, 2001

[86] Wagner R.G., Flynn J., Gregor R., Public perceptions of risk and acceptability of forest vegetation management alternatives in Ontario, For. Chron. 74 (1998) 720-727.

[87] Wagner R.G., Mohammed G.H., Noland T.L., Critical period of interspecific competition for northern conifers associated with herbaceous vegetation, Can. J. For. Res. 29 (1999) 890-897.

[88] Wall R.E., Biological control of red alder using stem treatments with the fungus Chondrostereum purpureum, Can. J. For. Res. 24 (1994) 1527-1530.

[89] Wall R.E., Fructification of Chondrostereum purpureum on hardwoods inoculated for biological control, Can. J. Plant Pathol. 19 (1997) 181-184.

[90] Walstad J.D., Kuch P.J., Forest vegetation management for conifer production, John Wiley \& Sons, New York, 1987.

[91] Walstad J., Newton M., Gjerstad D., Overview of vegetation management alternatives, in: Walstad J., Kuch P. (Eds.), Forest Vegetation Management for Conifer Production, New York, N.Y. 1987, pp. 157-200.

[92] Watkinson A.R., Freckleton R.P., Robinson R.A., Sutherland W.J., Predictions of biodiversity response to genetically modified herbicide-tolerant crops Science 289 (2000) 1554-1557.

[93] Weetman G., Distinctly Canadian silviculture and forest management, For. Chron. 77 (2001) 441-445.

[94] Wood J.E., Dominy S.W.J., Mechanical site preparation and early chemical tending in white spruce: 19-year results, For. Chron. 64 (1988) 177-181. 